\title{
MIR208B wt Allele
}

National Cancer Institute

\section{Source}

National Cancer Institute. MIR208B wt Allele. NCI Thesaurus. Code C82166.

The human MIR208B wild-type allele is located in the vicinity of $14 q 11.2$ and is approximately 76 bases in length. This allele, which encodes MIR208B pre-miRNA, plays a role in the regulation of gene expression. Alteration in the expression of this gene is associated with development of cardiac hypertrophy. 